\title{
Effects of Various Sintering Conditions on the Structural and Magnetic Properties of Zinc Ferrite $\left(\mathrm{ZnFe}_{2} \mathrm{O}_{4}\right)$
}

\author{
Poppy Puspitasari ${ }^{a, b *}$ (D), Ufsarah Anugrah Rizkia ${ }^{a}$, Sukarni Sukarni ${ }^{a, b}$ (D, Avita Ayu Permanasari ${ }^{a, b}$, \\ Ahmad Taufiq ${ }^{b, c}$ D, Andika Bagus Nur Rahma Putra ${ }^{a}$ \\ ${ }^{a}$ State University of Malang, Faculty of Engineering, Department of Mechanical Engineering, Semarang \\ 5, Malang, 65145, East Java, Indonesia \\ ${ }^{b}$ State University of Malang, Centre of Advanced Materials and Renewable Energy, Semarang 5 , \\ Malang, 65145, East Java, Indonesia \\ ${ }^{c}$ State University of Malang, Department of Physics, Semarang St. No. 5, Malang, 65145, East Java, \\ Indonesia
}

Received: July 07, 2020; Revised: October 22, 2020; Accepted: November 29, 2020

\begin{abstract}
Zinc ferrite $\left(\mathrm{ZnFe}_{2} \mathrm{O}_{4}\right)$ nanoparticles have attracted the attention of researchers because of their unique chemical properties and particle-size-dependent magnetic properties. High-surface-area spinel ferrites have numerous technical applications in areas such as high-density information storage, ferrofluids, and catalysis. The coprecipitation technique is the preferred method for preparing nanoscale $\mathrm{ZnFe}_{2} \mathrm{O}_{4}$ because it results in a small crystals with a uniform size distribution. In this study, the synthesis was conducted in solution for $48 \mathrm{~h}$, followed by sintering at $1000^{\circ} \mathrm{C}$ for $1.5-3.5 \mathrm{~h}$. The smallest crystals $(70.58 \mathrm{~nm}$ ) were found in the sample sintered for $2.5 \mathrm{~h}$. Fourier transform infrared spectroscopy (FTIR) functional-group analysis confirmed the presence of $\mathrm{Fe}-\mathrm{O}$ and $\mathrm{Zn}-\mathrm{O}$ bonds of cations in octahedral and tetrahedral sites. The $\mathrm{ZnFe}_{2} \mathrm{O}_{4}$ sintered for $3.5 \mathrm{~h}$ was superparamagnetic. The characterization results suggest that the obtained $\mathrm{ZnFe}_{2} \mathrm{O}_{4}$ could be used as a nanofluid in heat exchangers.
\end{abstract}

Keywords: Ferrite, Coprecipitation, Hysteresis, Sintering

\section{Introduction}

Studies on nanomaterials have become prevalent for several reasons, such as the need to produce new smallerscale materials to reduce the cost and increase information transmission and storage speeds. Another reason is that nanomaterials exhibit enhanced properties compared with conventional materials, which provides an opportunity for new technological applications. Theoretically, a nanomaterial is an element with a grain size of one per million meters ${ }^{1}$. Numerous authors have explored various aspects of nanomaterials, such as the possibility of controlling their size, defect concentration, solution concentration, atom interaction, and synthesis process ${ }^{2}$.

$\mathrm{ZnFe}_{2} \mathrm{O}_{4}$ is a critical technology material commonly used as a photocatalyst, a sorbent for desulfurizing hot coal gas, and a magnetic material in devices such as radio-frequency cores, sensors, and magnetic resonance imaging devices. $\mathrm{ZnFe}_{2} \mathrm{O}_{4}$ adopts the cubic spinel structure. Cations occupy one-eighth of the interstitial tetrahedral $(A)$ and one-half of the octahedral $(B)$ sites $^{3}$.

Among numerous spinel ferrites, $\mathrm{ZnFe}_{2} \mathrm{O}_{4}$ nanoparticles have attracted particular attention because of their unique chemical properties and thermal stability, as well as their particle-size-dependent magnetic properties ${ }^{4}$. Most spinel ferrites have a Curie temperature greater than room temperature, whereas $\mathrm{ZnFe}_{2} \mathrm{O}_{4}$ does not. Thus, $\mathrm{ZnFe}_{2} \mathrm{O}_{4}$ is compatible

*e-mail address: poppy@um.ac.id with most applications that require operating temperatures as high as $80^{\circ} \mathrm{C}^{5}$.

Bulk $\mathrm{ZnFe}_{2} \mathrm{O}_{4}$ crystallizes in the standard spinel structure with diamagnetic $\mathrm{Zn}^{2+}$ ions in the tetrahedral sites and magnetic $\mathrm{Fe}^{3+}$ ions in the octahedral sites. As a result of super antiferromagnetic interactions among octahedrally coordinated $\mathrm{Fe}^{3+}$ ions, bulk $\mathrm{ZnFe}_{2} \mathrm{O}_{4}$ becomes antiferromagnetic at its Néel temperature $\left(T_{\mathrm{N}}=10 \mathrm{~K}\right)$. However, when prepared at the nanometer scale, the structure of $\mathrm{ZnFe}_{2} \mathrm{O}_{4}$ is substantially different, with $\mathrm{Fe}^{3+}$ and $\mathrm{Zn}^{2+}$ cations occupying both octahedral and tetrahedral sites. As a result, nanocrystalline $\mathrm{ZnFe}_{2} \mathrm{O}_{4}$ exhibits ferromagnetic properties ${ }^{3}$.

The coprecipitation technique is the most appropriate approach for synthesizing $\mathrm{ZnFe}_{2} \mathrm{O}_{4}$ because it results in small crystals with a uniform distribution, is simple, and does not require a calcination step. On the basis of the theory underlying coprecipitation, several parameters (e.g., the counterions, ionic strength, $\mathrm{pH}$, and precipitation temperature) can influence the structure and magnetic properties of the resultant ferrite ${ }^{3}$. A previous investigation found that the chemical composition of $\mathrm{ZnFe}_{2} \mathrm{O}_{4}$ is influenced by the $\mathrm{Zn} /$ $\mathrm{Fe}$ molar ratio, $\mathrm{pH}$, sintering temperature, and sintering duration ${ }^{6}$. This previous study also showed that a $\mathrm{Zn} / \mathrm{Fe}$ ratio of 1:2 results in main diffraction peaks of $\mathrm{ZnFe}_{2} \mathrm{O}_{4}$ as well as secondary peaks of $\mathrm{Fe}_{2} \mathrm{O}_{3}$ and $\mathrm{ZnO}$. Varying the $\mathrm{pH}$ of the reaction solution resulted in different intensities of the main peak and in different amounts of precipitate. 
Sintering is the compaction process of powders at high temperatures below the melting point until there is a change in microstructure such as a reduction in the number and size of pores, grain growth, shrinkage, or increased density ${ }^{7}$. In the present work, sintered $\mathrm{ZnFe}_{2} \mathrm{O}_{4}$ is characterized using several methods: phase identification by X-ray diffraction (XRD) analysis, morphological analysis by scanning electron microscopy (SEM), and elemental composition analysis by energy-dispersive X-ray spectroscopy in conjunction with SEM (SEM-EDX). The functional groups are analyzed by Fourier transform infrared (FTIR) spectroscopy, and the magnetic properties are analyzed on the basis of hysteresis curves recorded at room temperature using a vibrating sample magnetometer (VSM) ${ }^{2}$. The objective of this research was to characterize the fine structure and properties of $\mathrm{ZnFe}_{2} \mathrm{O}_{4}$ as a potential sensor material.

\section{Method}

The coprecipitation synthesis method was used in the present work. In the first step, $\mathrm{ZnO}$ and $\mathrm{Fe}_{2} \mathrm{O}_{3}(2 \mathrm{~g}$ each) were dissolved into $40 \mathrm{~mL}$ of ethylene glycol using a magnetic stirrer at room temperature; the resultant solution was stirred for $48 \mathrm{~h}$ at $200 \mathrm{rpm}$ to ensure homogeneity. To neutralize the acidic solution, the obtained solution was titrated with $\mathrm{NaOH}$ until its $\mathrm{pH}$ was 12 . The solution was then heated at $70-80^{\circ} \mathrm{C}$ to form a gel. The sedimented material was washed three times with $1500 \mathrm{~mL}$ distilled water. The gel was then dried in an oven at $1100^{\circ} \mathrm{C}$ until it turned into a dry powder. The dried gel was crushed for $1 \mathrm{~h}$ and then sintered at $1000^{\circ} \mathrm{C}$ for $1.5,2.5$, or $3.5 \mathrm{~h}$. The sintered powder was then characterized by XRD (PANalytical) with $\mathrm{Cu} \mathrm{K} \alpha$ $(\lambda=1.54 \AA)$ radiation to determine its phase and crystal size. The morphology was characterized by SEM (Phenom). The functional groups were characterized by FTIR analysis (IRPrestige21), and the magnetic properties were characterized using an Oxford 1.2H VSM.

\section{Results and Discussion}

Figure 1 shows SEM images of the $\mathrm{ZnFe}_{2} \mathrm{O}_{4}$ synthesized using the coprecipitation method and sintered at $1000^{\circ} \mathrm{C}$ for $1.5,2.5$, and $3.5 \mathrm{~h}$. The micrographs show that the materials tend to have cubic crystallites. Figure $1 \mathrm{a}$ and $1 \mathrm{c}$ show changes in the material structure, with greater agglomeration than observed in Figure 1b. The sintering time at $1000^{\circ} \mathrm{C}$ strongly influenced the change in morphology. The heat treatment induces bonding between among particles and increases the strength of the obtained product ${ }^{8}$. The sintering process strongly affects the formation of the crystalline phase of the material. The phase fraction formed generally depends on the sintering time and temperature ${ }^{9}$.

Figure 2 shows the XRD patterns of $\mathrm{ZnFe}_{2} \mathrm{O}_{4}$ sintered at $1.5-3.5 \mathrm{~h}$. The XRD patterns show diffraction peaks corresponding to the (220), (311), (400), (422), (511), and (440) planes of the spinel structure. The observed peaks were

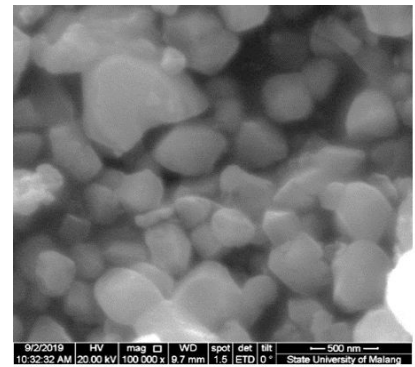

(a) $1.5 \mathrm{~h}$

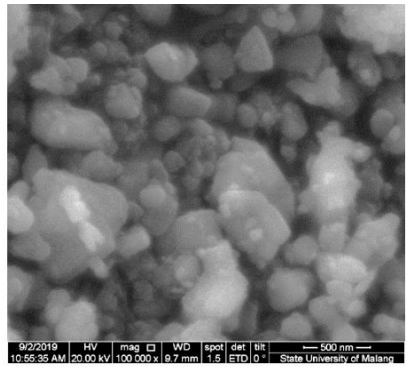

(a) $2.5 \mathrm{~h}$

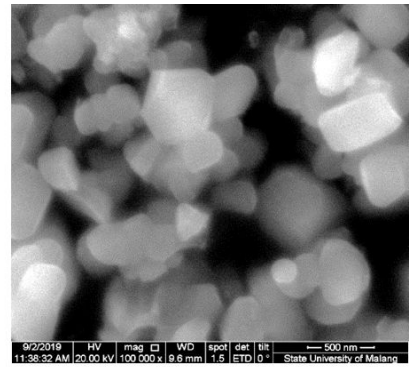

(a) $3.5 \mathrm{~h}$

Figure 1. SEM morphology of $\mathrm{ZnFe}_{2} \mathrm{O}_{4}$ sintered for (a) $1.5 \mathrm{~h}$, (b) $2.5 \mathrm{~h}$ and (c) $3.5 \mathrm{~h}$; all images are at 100,000× magnification.

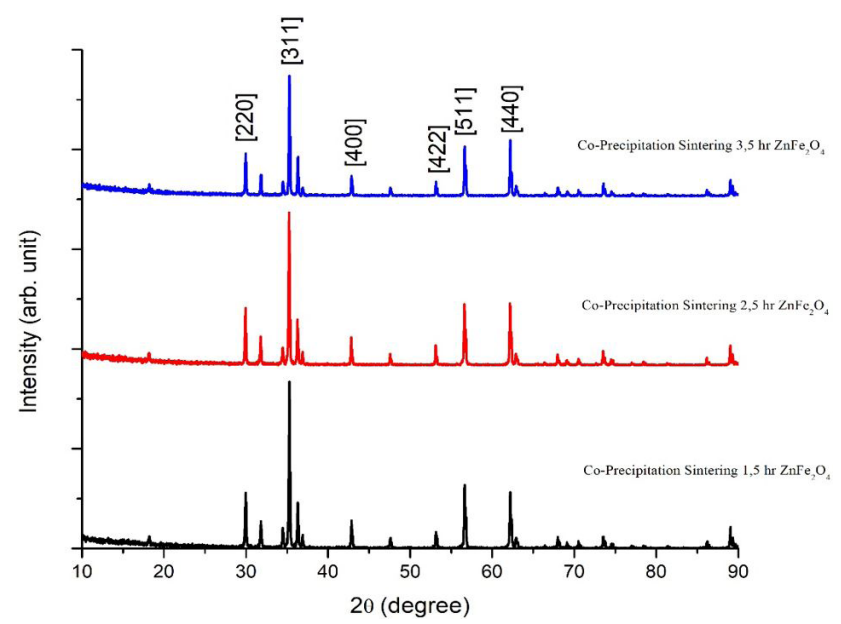

Figure 2. $\mathrm{ZnFe}_{2} \mathrm{O}_{4}$ phase identification of samples sintered for various durations. 
compared with those specified in the ICDD PDF (22-1012) reference pattern and were concluded to correspond to a single-phase cubic spinel-structured material. No additional peaks were observed in the patterns, indicating that the synthesized product was free of impurities ${ }^{10}$. The samples exhibited similar particle sizes (smaller than $90 \mathrm{~nm}$ ) irrespective of the sintering duration $(1.5,2.5$, or $3.5 \mathrm{~h})$. The sample sintered for $2.5 \mathrm{~h}$ exhibited the smallest grain size of $70.58 \mathrm{~nm}$; thus, the sintering duration strongly influenced the grain size ${ }^{11}$. The particles shrank with increasing sintering time, resulting in the gradual removal of water fom the crystal lattice ${ }^{12}$. The samples sintered for $1.5,2.5$, and 3.5 h exhibited particle sizes of 84.72, 70.58, and $84.72 \mathrm{~nm}$, respectively, and main peak heights of 836.72 , $767.80,609.98$ counts in their XRD patterns, respectively (Table 1). These results are attributed to an increase in the growth activity of nanoparticles with increasing temperature because of the influence of heat during the synthesis process ${ }^{4}$. Particle size depends on numerous factors, including the synthesis conditions, sintering temperature, time, and the rate of heating and cooling ${ }^{13}$. The lattice parameter of the synthesized nanoparticles was greater than that of bulk $\mathrm{ZnFe}_{2} \mathrm{O}_{4}(a=8.441 \AA)$ (JCPDS No. 22-1012). This sample is an example of $\mathrm{ZnFe}_{2} \mathrm{O}_{4}$ nanoparticles with a mixture of normal and inverse spinel structures. The substitution of several $\mathrm{Fe}^{3+}$ cations for $\mathrm{Zn}^{2+}$ cations, whose ionic radius $(0.74 \AA)$ is larger than that of $\mathrm{Fe}^{3+}(0.64 \AA)$, results in an expansion of the spinel lattice, with a concomitant increase in the corresponding lattice parameter ${ }^{4}$.

In the normal $A B_{2} \mathrm{O}_{4}$ spinel structure, $A$ is generally a divalent cation that occupies tetrahedral sites, whereas $B$ is a trivalent cation that occupies octahedral sites. Bulk $\mathrm{ZnFe}_{2} \mathrm{O}_{4}$ is a completely normal spinel structure with $\mathrm{Zn}^{2+}$ ions at the tetrahedral $(A)$ sites and $\mathrm{Fe}^{3+}$ ions at the octahedral $(B)$ sites. In fact, when $\mathrm{ZnFe}_{2} \mathrm{O}_{4}$ is prepared at the nanoscale, the high surface energy associated with the small particle size leads to the distribution of mixed cations, where $\mathrm{Zn}^{2+}$ ions and $\mathrm{Fe}^{3+}$ ions are distributed among $A$ and $B$ sites, giving rise to mixed spinel structures. This difference is attributed to cation distribution defects ${ }^{14,15}$.

Figure 3 displays the FTIR spectra of $\mathrm{ZnFe}_{2} \mathrm{O}_{4}$ in the wavenumber region $4000-400 \mathrm{~cm}^{-1}$. The functional groups of $\mathrm{ZnFe}_{2} \mathrm{O}_{4}$ sintered for various times are similar except in the case of the sample sintered for $2.5 \mathrm{~h}$, whose spectrum shows additional peaks in the $0-500 \mathrm{~cm}^{-1}$ range. The main peaks of $\mathrm{ZnFe}_{2} \mathrm{O}_{4}$ are observed in the range $400-600 \mathrm{~cm}^{-1}$, representing $\mathrm{Fe}-\mathrm{O}$ and $\mathrm{Zn}-\mathrm{O}$ bonds ${ }^{10,16,17}$ involved in metal-oxygen vibration stretching in octahedral and tetrahedral sites ${ }^{18,19}$. The strong absorption peak at $\sim 1508 \mathrm{~cm}^{-1}$ corresponds to the $\mathrm{C}=\mathrm{C}$ stretching vibration ${ }^{20}$ and indicates the presence of surface hydroxyl groups ${ }^{19}$ or moisture ${ }^{18}$. The peak at $\sim 2300 \mathrm{~cm}^{-1}$ represents stretching vibrations of ether groups with $\mathrm{C}=\mathrm{O}$ and $\mathrm{N}-\mathrm{H}$ or $\mathrm{O}-\mathrm{H}^{21}$ either the peak corresponding to the $\mathrm{O}-\mathrm{H}\left(\mathrm{H}_{2} \mathrm{O}\right.$ bending mode $)$ group indicates the conversion of water to steam in the $\mathrm{ZnFe}_{2} \mathrm{O}_{4}$ nanoparticles ${ }^{17,18,20}$. A decrease in intensity of the lower-frequency peaks might be caused by the formation of a $\mathrm{H}$ bridge on the precursor, which subsequently disappears upon thermal treatment ${ }^{22-24}$.

The hysteresis curve of $\mathrm{ZnFe}_{2} \mathrm{O}_{4}$ sintered at $1000^{\circ} \mathrm{C}$ for 1.5 , and $2.5 \mathrm{~h}$ indicates a nonmagnetic material; no hysteresis curve with an apparent magnetic saturation $\left(M_{\mathrm{s}}\right)$ or coercivity $\left(H_{c}\right)$ was observed (Figure 4). Table 2 shows that the sample

Table 1. $\mathrm{ZnFe}_{2} \mathrm{O}_{4}$ Crystal Characteristics Obtained from XRD Analysis

\begin{tabular}{cccccc}
\hline Sintering Duration & $\mathbf{2 \theta}$ (degree) & Height $(\mathbf{c t s})$ & $\boldsymbol{d}$-Spacing $[\AA \boldsymbol{\AA}]$ & FWHM $(\boldsymbol{\beta})$ & Crystal Size (nm) \\
\hline 1.5 & 35.28 & 836.72 & 2.54 & 0.0984 & 84.72 \\
\hline 2.5 & 35.25 & 767.80 & 2.54 & 0.1181 & 70.58 \\
\hline 3.5 & 35.28 & 609.98 & 2.54 & 0.0984 & 84.72 \\
\hline
\end{tabular}

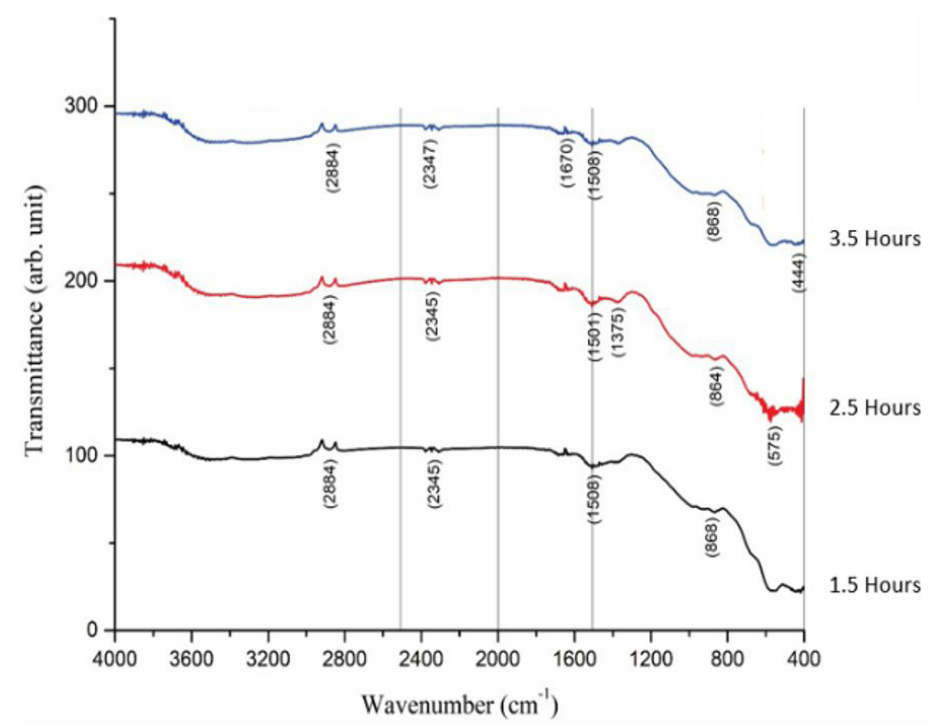

Figure 3. $\mathrm{ZnFe}_{2} \mathrm{O}_{4}$ functional-group identification of samples sintered for different durations. 
Table 2. Magnetic Properties of $\mathrm{ZnFe}_{2} \mathrm{O}_{4}$

\begin{tabular}{cccccc}
\hline Sintering Time & $\begin{array}{c}\text { Magnetic } \\
\text { Saturation } / \boldsymbol{M}_{\boldsymbol{s}} \\
(\mathbf{e m u} / \mathbf{g})\end{array}$ & $\begin{array}{c}\text { Magnetic } \\
\text { Remanence/ } \boldsymbol{M}_{\boldsymbol{r}} \\
(\mathbf{e m u} / \mathbf{g})\end{array}$ & $\begin{array}{c}\text { Remanence } \\
\text { Ratio } / \boldsymbol{M}_{\mathbf{r}} / \boldsymbol{M}_{\mathbf{s}}\end{array}$ & \multicolumn{2}{c}{ Coercivity $/ \boldsymbol{H}_{\mathbf{c}}$} \\
\hline $1.5 \mathrm{~h}$ & 1.12 & -0.06 & -0.054 & 0 & Oe \\
\hline $2.5 \mathrm{~h}$ & 1.15 & -0.04 & -0.035 & 0 & 0 \\
\hline $3.5 \mathrm{~h}$ & 52.52 & 14.42 & 0.028 & 0.0708 & 708 \\
\hline
\end{tabular}

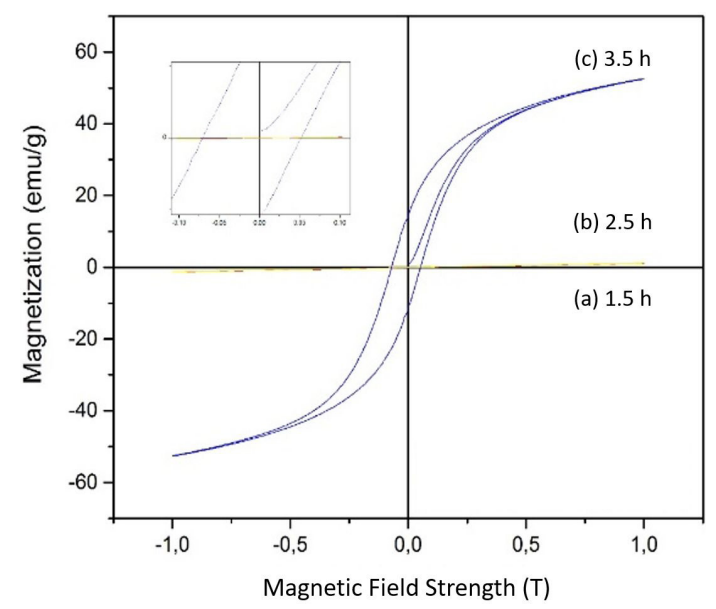

Figure 4. Hysteresis VSM curves for $\mathrm{ZnFe}_{2} \mathrm{O}_{4}$ sintered for (a) $1.5 \mathrm{~h}$, (b) $2.5 \mathrm{~h}$, and (c) $3.5 \mathrm{~h}$.

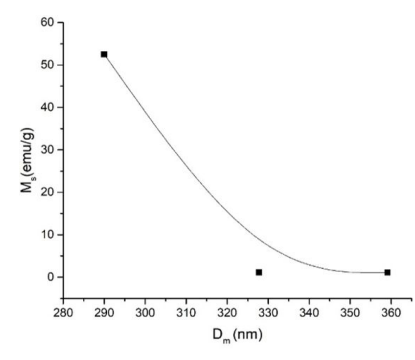

(a)

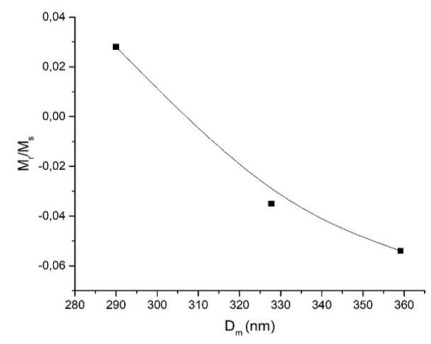

(b)

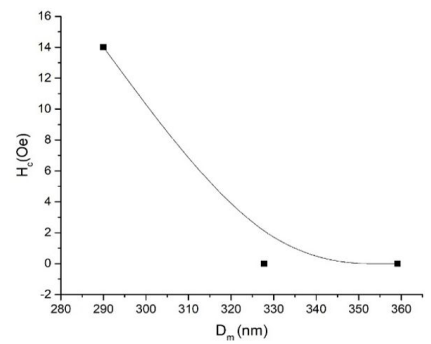

(c)

Figure 5. Correlation of the particle size of $\mathrm{ZnFe}_{2} \mathrm{O}_{4}$ with its (a) magnetic saturation, (b) remanence ratio, and (c) coercivity.

sintered for $3.5 \mathrm{~h}$ exhibits an $M_{\mathrm{s}}$ value of $52 \mathrm{emu} / \mathrm{g}$ and a $H_{\mathrm{c}}$ of 0.0708 T. An S-shape hysteresis curve ${ }^{25}$ and a $H_{\mathrm{c}}$ value close to zero indicates a superparamagnetic material ${ }^{10}$. Such an increase in the $H_{\mathrm{c}}$ value can be achieved with single-domain crystallites because of the magnetization process due to spin-orbit rotation without domain wall movement ${ }^{26}$. These results indicate that the sintering duration greatly influenced the magnetic properties of the $\mathrm{ZnFe}_{2} \mathrm{O}_{4}$. The longer sintering duration of $3.5 \mathrm{~h}$ for $\mathrm{ZnFe}_{2} \mathrm{O}_{4}$ caused spin-orbit coupling with various hyperfine structures ${ }^{27}$ and superexchange interactions ${ }^{28}$ between the spin electron in $\mathrm{ZnO}$ and $\mathrm{Fe}_{2} \mathrm{O}_{3}$. The magnetization of spinnel ferrite is given by super-exchnage interaction of side $\mathrm{A}$ and $\mathrm{B}$. In bulk zinc ferrites, $\mathrm{Zn}^{2+}$ ions of zero moment and $\mathrm{Fe}^{3+}$ ions fill $\mathrm{A}$ and $\mathrm{B}$ sites respectively. Few $\mathrm{Fe}^{3+}$ ions may occur $\mathrm{A}$ site and has possibility of $\mathrm{AB}$ interaction. In the probability distribution of magnetic hyperfine fields, the superparamagnetic behaviour at $3.5 \mathrm{~h}$ samples because there is an occupancy of some $\mathrm{Fe}^{3+}$ ions migrates from $\mathrm{B}$ to A side. Therefore, it will disturb the antiparallel ordering of B site and enhance the saturation magnetization and magnetic moment ${ }^{29}$.
At room temperature, the magnetic properties arise due to the formation of superparamagnetic domains. The absence of hysteresis, immeasurable magnetic remenance, coercivity, and the non-attainment of saturation indicate the presence of superparamagnetic behaviour ${ }^{30}$.

Figure 5 displays the calculated magnetization data in charts that compare particle size $\left(D_{\mathrm{m}}\right)$ with the $M_{\mathrm{s}}, D_{\mathrm{m}}$ with the remanence ratio $\left(M_{\mathrm{r}} / M_{\mathrm{s}}\right)$, and $D_{\mathrm{m}}$ with the $H_{\mathrm{c}}$. The results show that, on the basis of the average particle size obtained from the SEM images, longer sintering times led to smaller particles and more substantial $M_{\mathrm{s}}$ values. These results are attributed to a decrease in cationic disorder, which in turn decreased the $D_{\mathrm{m}}{ }^{26}$. Similarly, a smaller $D_{\mathrm{m}}$ led to greater $H_{\mathrm{c}}$. This variation is related to a favorable particle size as a result of the cation distribution between sites ${ }^{31}$. The relationship between the $D_{\mathrm{m}}$ and the $M_{\mathrm{r}} / M_{\mathrm{s}}$ ratio, which was inversely proportional to the particle size, is consistent with the relationship between the $D_{\mathrm{m}}$ and the $M_{\mathrm{s}}$. The substantial magnetization values show that the cation distribution changed from normal spinel type to mixed spinel type ${ }^{28}$. 


\section{Conclusion}

The morphological identification and SEM-EDX elemental analysis of $\mathrm{ZnFe}_{2} \mathrm{O}_{4}$ synthesized via the coprecipitation method showed that the sample sintered for $2.5 \mathrm{~h}$ exhibited less agglomeration than the samples sintered for 1.5 or $3.5 \mathrm{~h}$. The elemental composition indicated that the samples were free of impurities, and the XRD phase identification showed that the sample sintered for $2.5 \mathrm{~h}$ crystallized in the cubic spinel structure with the smallest particle size $(70.58 \mathrm{~nm})$ among the investigated samples. The FTIR functional-group characterization confirmed the presence of vibrations due to $\mathrm{Fe}-\mathrm{O}$ and $\mathrm{Zn}-\mathrm{O}$ bonds of cations in the octahedral and tetrahedral sites in the $400-600 \mathrm{~cm}^{-1}$ wavenumber range. The peak at $3400 \mathrm{~cm}^{-1}$ indicated the presence of $\mathrm{O}-\mathrm{H}$ groups of water steam due to sintering of the $\mathrm{ZnFe}_{2} \mathrm{O}_{4}$ material.

The hysteresis curves showed that $\mathrm{ZnFe}_{2} \mathrm{O}_{4}$ sintered for $3.5 \mathrm{~h}$ was superparamagnetic, with $M_{\mathrm{s}}=52 \mathrm{emu} / \mathrm{g}$ and $H_{\mathrm{c}}=0.0708 \mathrm{~T}$, whereas the samples sintered for 1.5 and $2.5 \mathrm{~h}$ were nonmagnetic. According to these results, the sintering duration did not influence the magnetic properties of $\mathrm{ZnFe}_{2} \mathrm{O}_{4}$. The magnetization value in this research showed that the cation distribution changed from normal spinel type to mixed spinel type.

\section{Acknowledgments}

Our sincere thanks to the RISTEKBRIN for the research funding for PP.

\section{References}

1. Gajanan K, Tijare SN. Applications of nanomaterials. Mater Today Proc. 2018;5(1):1093-6.

2. Sasongko MIN, Puspitasari P, Sukarni, Yazirin C. Properties of $\mathrm{MnO}$ doped graphene synthesized by co-precipitation method. Funct Mater. 2018;25(4):802-8.

3. Milanović M, Moshopoulou EG, Stamopoulos D, Devlin E, Giannakopoulos KP, Kontos AG, et al. Structure and magnetic properties of $\mathrm{Zn}_{1-x \operatorname{lnx}} \mathrm{Fe}_{2} \mathrm{O}_{4}$ and $\mathrm{ZnY}_{\mathrm{x}} \mathrm{Fe}_{2-\mathrm{x}} \mathrm{O}_{4}$ nanoparticles prepared by coprecipitation. Ceram Int. 2013;39(3):3235-42.

4. Asmin LO, Mutmainnah, Suharyadi E. Sintesis nanopartikel zinc ferrite ( $\mathrm{ZnFe} 2 \mathrm{O} 4)$ dengan metode kopresipitasi dan karakterisasi sifat kemagnetannya. J Fis dan Apl. 2015;16(3):62-6.

5. Zaag PVD. Ferrites. Ref Modul Mater Sci Mater Eng. 2015;2016:17.

6. Ping R, Junxi Z, Huiyong D. Preparation and microstructure of spinel zinc ferrite $\mathrm{ZnFe} 2 \mathrm{O} 4$ by co-precipitation method. J Wuhan Univ Technolotgy-Mater. 2009;24(6)927-30.

7. Sri Mantia Y, Ramli, Darvina Y, Desnita. Pengaruh suhu sintering terhadap sifat penyerap gelombang mikro dari nanokomposit $\mathrm{CoFe}_{2} \mathrm{O}_{4} / \mathrm{PVDF}$ yang dipreparasi dengan metode sol gel. Pillar Phys. 2019;12:91-7.

8. German RM. Sintering: from empirical observations to scientific principles. USA: Elsevier; 2014. p. 413-32.

9. Suarsana K, Astika IM, Sunu PW. Properties of thermal conductivity, density, and hardness of alumunium matrices with reinforcement of $\mathrm{SiCw} / \mathrm{A} 12 \mathrm{O} 3$ hybrid after sintering process. IOP Conference Series Materials Science and Engineering. 2016;539:012016.

10. Sivagurunathan P, Sathiyamurthy K. Effect of temperatures on structural, morphological and magnetic properties of zinc ferrite nanoparticles. Can Chem Trans Year. 2016;4(2):244-54.

11. Yazirin C, Puspitasari P, Sasongko MIN, Tsamroh DI, Risdanareni P. Phase identification and morphology study of hematite $\left(\mathrm{Fe}_{2} \mathrm{O}_{3}\right)$ with sintering time varitions. AIP Conf Proc. 2017;1887(1):020038.
12. Shijie $C$, Jingbing $X$, Jianqing D. Effects of heating processing on microstructureand magnetic properties of $\mathrm{Mn}-\mathrm{Zn}$ ferrites prepared via chemical co-precipitation. Journal of Wuhan University of Technology-Mater. Sci. Ed. 2015;30:684-8.

13. Hossain MS, Hoque SM, Liba SI, Choudhury S. Effect of synthesis methods and a comparative study of structural and magnetic properties of zinc ferrite. AIP Adv. 2017;7:105321.

14. El Maalam K, Fkhar L, Mahhouti Z, Mounkachi O, AitAli M, Hamedoun M, et al. The effects of synthesis conditions on the magnetic properties of zinc ferrite spinel nanoparticles. J. Phys.: Conf. Ser. 2016;758:012008.

15. Singh JP, Payal RS, Srivastava RC, Agrawal HM, Chand P, Tripathi A, et al. Effect of thermal treatment on the magnetic properties of nanostructured zinc ferrite. J. Phys.: Conf. Ser. 2010;217:012108.

16. Fajaroh F, Susilowati ID, Nazriati, Sumari, Nur A. Synthesis of $\mathrm{ZnFe} 2 \mathrm{O} 4$ nanoparticles with $\mathrm{PEG} 6000$ and their potential application for adsorbent. IOP Conf Ser Mater Sci Eng. 2019;515:012049.

17. Din IU, Tasleem S, Naeem A, Shaharun MS, Al Kaisy GMJ. Zinc ferrite nanoparticle synthesis and characterization; effects of annealing temperature on the size of nanoparticles. Aust J Basic Appl Sci. 2013;7(4):154-62.

18. Vinosha PA, Anceila D, Mely LA, Priya SD, Rodney JD, Das SJ. Studies on structural, optical and magnetic properties of zinc ferrite nanoparticles. Int. Res. J. Eng. Tech. (Online). 2017;4(9):342-44.

19. Matli PR, Zhou X, Shiyu D, Huang Q. Fabrication, characterization, and magnetic behavior of porous $\mathrm{ZnFe}_{2} \mathrm{O}_{4}$ hollow microspheres. Int Nano Lett. 2015;5(1):53-9.

20. Rameshbabu R, Ramesh R, Kanagesan S, Karthigeyan A, Ponnusamy S. Synthesis and study of structural, morphological and magnetic properties of $\mathrm{ZnFe}_{2} \mathrm{O}_{4}$ nanoparticles. J Supercond Nov Magn. 2014;27(6):1499-502.

21. Goodarz Naseri M, Saion EB, Kamali A. An overview on nanocrystalline $\mathrm{ZnFe}_{2} \mathrm{O}_{4}, \mathrm{MnFe}_{2} \mathrm{O}_{4}$, and $\mathrm{CoFe}_{2} \mathrm{O}_{4}$ synthesized by a thermal treatment method. ISRN Nanotechnol. 2012;2012:1-11.

22. Ladole CA. Preparation and characterization of spinel zinc ferrite $\mathrm{ZnFe}_{2} \mathrm{O}_{4}$. Int J Chem Sci. 2012;10(3):1230-4.

23. Risdanareni P, Puspitasari P, Jaya EJ. Chemical and physical characterization of fly ash as geopolymer material. MATEC Web of Conferences. 2017;97:01031.

24. Sukarni, Sumarli, Puspitasari, P., Suryanto, H. \& Wati, R. F. Physicochemical characteristics of various inorganic combustible solid waste (ICSW) mixed as sustainable solid fuel. in 020066 (2017). doi:10.1063/1.5003549.

25. Shahraki RR, Ebrahimi M. Synthesize of superparamagnetic zinc ferrite nanoparticles at room temperature. J Nanostructures. 2013;2:413-6.

26. Mendonça EC, Jesus CBR, Folly WSD, Meneses CT, Duque JGS. Size effects on the magnetic properties of $\mathrm{ZnFe} 2 \mathrm{O} 4$ nanoparticles. J Supercond Nov Magn. 2013;26(6):2329-31.

27. Jin $\mathrm{C}$, Li P, Mi W, Bai H. Structure, magnetic, and transport properties of epitaxial $\mathrm{ZnFe} 2 \mathrm{O} 4$ films: an experimental and first-principles study. J Appl Phys. 2014;115:213908.

28. Deraz NM, Alarifi A. Microstructure and magnetic studies of zinc ferrite nano-particles. Int J Electrochem Sci. 2012;7(7):6501-11.

29. John SP, Mathew J. Determination of ferromagnetic, superparamagnetic and paramagnetic components of magnetization and the effect of magnesium substitution on structural, magnetic and hyperfine properties of zinc ferrite nanoparticles. J Magn Magn Mater. 2019;475:160-70.

30. Farooq H, Ahmad MR, Jamil Y, Hafeez A, Anwar M. Structural, dielectric and magnetic properties of superparamagnetic zinc ferrite nanoparticles synthesized through coprecipitation technique. Kov Mater. 2013;15(5):1-6.

31. Zawar S, Atiq S, Riaz S, Naseem S. Correlation between particle size and magnetic characteristics of Mn-substituted $\mathrm{ZnFe}_{2} \mathrm{O}_{4}$ ferrites. Superlattices Microstruct. 2016;93:50-6. 